Kohl: a Journal for Body and Gender Research Vol. 6, No. 3 (Winter 2020)

\title{
Queer Spatial Recognition in Kuwait
}

Nour Almazidi

\begin{abstract}
:
In this research, I am concerned with giving an account of queer spaces that are formed through social relations and have fostered a form of "spatial recognition" and inhabitation. Rather than positioning these spaces as resistant, I want to situate them through an analysis that takes into account the political economy of Kuwait and the classed apparatus of citizenship that structures mechanisms of social control and informs social dynamics between citizens and non-citizens. Through giving this account, my aim is to think about recognition beyond legal frameworks that are attached to notions of visibility and "coming out."
\end{abstract}




\section{Introduction}

Four summers ago, I moved back to Kuwait for a few months in-between my studies. I had been living in the UK since 2012 and so upon my return, I was anxious about how to navigate my social life as a young adult with very few friendships maintained online and through social media. I was unsure how to meet new people, form new connections, relationships, and friendships, and find spaces that invoked the sense of collectivity and belonging that I had been searching for - a sense of belonging and intimacy that I hadn't been able to find during my time in the UK either. But in August, at the height of a Kuwaiti summer, I was waiting under the blazing hot sun for about ten minutes before Nidhal picked me up, and we set to head for a friends' gathering at a chalet. Nidhal and I had initially met on Twitter, and although we had spent time together in person many times before, this was the first summer we were able to see each other in Kuwait and it was an opportunity for them to introduce me to their friends and acquaintances; some I had known before, others, I met for the first time. I felt anxious on the way, given that the journey was long and I knew there was a possibility that we would come across a police checkpoint. At the time, I had long known about the anxieties, tensions, and harassment that can unfold at the checkpoint for queer people who visibly present themselves in, what is considered, non-normative ways. Luckily, we arrived at the chalet without such an interpellation. We spent the day swimming, listening to music, and having meaningful conversations. Much of this article is driven by an attempt to articulate a feeling I had first experienced being in such a space, a feeling that would later continue to inhabit the spaces I spend most of my time in today.

The links that are made between queerness, visibility, recognition, and sexual liberation that often saturate hegemonic, U.S.-informed representations of queer life and experiences did not apply to this context. This was a space where queer sexualities and genders were recognised and acknowledged by friends and some family members; nonetheless, neither did it emerge from a sexual rights framework, nor did it operate as a model of queer visibility. How does one language a phenomenology of this form of queer spatial intimacy? What are the affective registers that transcend the failure of words to convey such a space as intelligible? And what does this account mean for understandings of queer intimacies, subjectivities and queerness more broadly? Like Jaha and Kawthar expressed at the Queer Feminisms Workshop in 2019, I wanted to meditate on how to provide an account of "the types of tapestries, the colours and fabrics," the smells, the textures, the music, "the geographies and the sights and the sounds" that shaped the corporeality of queer spatial ontologies. In this research, I am concerned with giving an account of spaces that can be understood "as part of a constellation of sites" (Sinnott, 2013, p.343) that are formed through social relations and have fostered a form of "spatial recognition" and inhabitation. Rather than positioning these spaces as resistant, I want to situate them through an analysis that takes into account the political economy of Kuwait and the classed apparatus of citizenship that structures mechanisms of social control and informs social dynamics between citizens and non-citizens. Through giving this account, my aim is to think about recognition beyond legal frameworks that are attached to notions of visibility and "coming out."

Transnational activist efforts have greatly contributed to the "human rights turn" in LGBT rights politics, and much of it has accompanied national and domestic legal changes in Euro-America and many states in the global South (Kollman \& Waites, 2009, pp.4-7). Here, I am concerned with a particular apparatus of representational politics produced by Western LGBT rights discourses that invoke homonormative and 
homonationalist (Puar, 2007) narratives. Lisa Duggan has foregrounded concerns about "the new homonormativity," arguing of the dangers of laying rights claims "around the right of access to the trappings of heteronormative privilege" (Bell \& Binnie, 2006, p.870; Duggan, 2003). Homonormativity operates as "a politics that does not contest dominant heteronormative assumptions and institutions, but upholds and sustains them, while promising the possibility of a demobilized gay constituency and a privatized, depoliticized gay culture anchored in domesticity and consumption" (Duggan 2002, 179). The deployments of sexual rights have become central to the constitution of the West as a normative power, continuing the presentation of Euro-America as liberatory, just, and progressive, and thus allowing for sexual rights and women's rights to be invoked as "a facet of modernity" (Puar, 2013, p.337) and even as a way of legitimising the "war on terror" (Butler, 2009; Mahmood, 2008). Homonationalism describes an "uneasy yet urgent" re-articulation of the relationship between "the state, capitalism, and sexuality" where the conditional incorporation of some queer bodies (hence, imaginative) into heteronormative and nationalist rhetoric works to provide understandings of the Western national Self in the language of sexual exceptionalism vis-à-vis the backwards racialised sexual Other (Puar, 2006, p.70; Puar, 2013, p.337). The global conditions of homonationalism enable state practices such as pinkwashing, or "Israel's promotion of a LGTBQ-friendly image to reframe the occupation of Palestine in terms of civilizational narratives measured by (sexual) modernity" (Ibid.). This is also where we note a proliferation in rescue narratives and a "saving gays" industry found in mainstream media and political discourses that affectively focus on queer persecution in the non-West and LGBT asylum claims. In "Can the Subaltern Speak?," Gayatri Chakravorty Spivak points to the role of colonial fantasies of "white men saving brown women from brown men" (Spivak, 1993, p.92) and how that plays into civilisationalist discourses. Similarly, the now additional "saving brown queers" agenda operates at the level of postmodern coloniality whose concern is emancipating the suffering closeted queer (Bracke, 2012). And while I reiterate queer critiques of the limitations and deployments of rights, and the workings of a politics of assimilation within a constitutional recognition of sexual rights, I am not putting forth such arguments as to undermine or oppose the importance of the legal protection that is produced through rights and policies; after all, as Spivak notes, one cannot not want rights (Spivak, 1993, p.45). What is at stake here is that the insistence on thinking about recognition only in the language of legal change is dismissive of accounts of the different ways in which queer bodies inhabit and struggle against norms.

Bell \& Binnie have shown that when marginalised identities, desires and practices are mainstreamed through the language of sexual rights and visibility, new trajectories open out "the sphere of sexual citizenship... away from a narrowly prescribed normativity" (Bell \& Binnie, 2006, p.870). Yet, I am mainly concerned with how understandings of queer recognition and visibility become relegated and limited to the legal sphere and to "coming out" tropes. When "coming out" narratives are represented as a form of queer resistance, "out of which arises a properly self-realized queer subject," the inability or refusal to "come out" becomes interpreted as the ultimate sign of suffering (Ritchie, 2010, p.151). As "geopolitical mappings of homophobia" (Dhawan, 2013, p.200) cast Gulf countries like Kuwait to the realm of sexual oppression and provide a uniformed understanding of non-normative genders and sexualities in Kuwait, the agency of queer subjects is erased. The "presumed tyranny of the closet," lack of visibility, and "recognition" as it is understood further essentialise the monolithically produced "Arab cultures" whose understandings of sexuality are forever stuck in the pre-modern, pre-political, unliberated past (Ritchie, 2010, p.566). This epistemo-political account forecloses any possibility for the existence of the spaces I am concerned with. In this research, I want to challenge such reductive representational narratives 
through exploring how queer life in Kuwait can be inhabited and lived in ways that are not only mobilised around questions of legal and political recognition and visibility, but are felt through time and space. Using ethnographic research methodologies, I reflect on a queer enjoyment of social and sexual relations in spaces of a felt recognition, spaces that are not necessarily "transgressive" to homophobic and transphobic state power and social control invested in binary sex/gender, but rather constitute "a political disturbance" (Ahmed, 2004) in their inhabitation of norms that are embedded in power relations.

In my focus on queer life in Kuwait, I hope this research can be posed as an open dialogue and a continuing conversation within Middle East queer studies; a conversation that is "sometimes comfortable, sometimes tense" (Traub, 2008, p.2) in its insistence on productive understandings of the "transformation and fluctuation of the discourses on sexuality in Middle Eastern cultural production" (Al-Samman \& ElAriss, 2013, p.205). Hanadi Al-Samman and Tarek El-Ariss introduce a new set of epistemic interventions that mark a shift from a focus on representational and Othering discourses on queer Middle Eastern sexuality solely as an outcome of hegemonic colonial powers towards a fuller engagement with queerness "in moments of play, performance, contradiction, dissonance, and evanescence" (Ibid.). It is these sometimes ephemeral and momentary, sometimes long-lasting textures of queer life in space that I seek to capture.

\section{Methodology and Researcher's Positionality}

One of the primary ways through which feminist theory has challenged research engagements in social sciences is through its critiques of "existing fantasies of objective knowledge produced by autonomous subjects" (Hemmings, 2012) that unnerve understandings of knowledge as neutral and demonstrate the power-imbued and value-laden facet of knowledge production (Harding, 1993). In ongoing conversations around subalternity, voice, representation, and authorship, key feminist theoretical interventions have stressed the importance of "taking subjectivity into account" (Code, 1993), acknowledging the "situatedness" of knowledges (Haraway, 1990) and engaging positionality and reflexivity throughout the research. Acknowledging the researcher's positionality through the employment of self-reflexive practices means giving an account of how the research is shaped by the intersections of gender, race, class, sexuality, ethnicity, and other shifting aspects of the researcher's identity within the context of the research. It is not simple "naval gazing" (Nagar, 2002, p.180) but is rather a commitment to maintaining an awareness of the power dynamics between the researcher and the researched subjects.

I enter, navigate, and inhabit the text as another participant of the social scene I am trying to give an account of. One way for one to describe the queer "scene" in Kuwait and develop a set of intimate and fruitful descriptions of how queers in Kuwait are subjectivated by the political realities and geography within which they exist, is to be a participant in this milieu. In many ways, the production of this research would not have been possible had I not already been considered someone who is part of the spaces I am concerned with. During initial stages of this research, I was positioned as a friend who had returned home for a short period of time and was trusted with access to some very intimate aspects of my participants' lives. Establishing rapport with my participants was made easier by previous connections I had made during my time in Kuwait. My participants included friends, acquaintances, and new participants that I had only met through this research process. Their ages ranged from 22 to 30 , and they 
consisted of Kuwaiti nationals apart from two participants who were non-citizens. I use borrowed names throughout the text to maintain participants' confidentiality. Given Kuwait's patriarchal gender structures, homophobia, and transphobia in the state's regulations of gender and sexual non-normativity, the interviews had to be conducted in complete secrecy. Informed by the ethnography and initial set of interviews, I read the data generated against Human Rights Watch reports, legal documents on Kuwait's penal code, news reports of mainly queer migrant persecutions in Kuwait, videos of parliamentary sessions and talk shows, scholarly works on Kuwait's history and politics, and my own past and current experiences of navigating these questions in Kuwait. I am hoping that providing this ethnographic encounter can disrupt Eurocentric production of queer knowledges that are attached to sexual rights frameworks and dominant narrations of queer life and intimacy while also moving beyond some of the limitations of available reports on queerness in Kuwait.

I began this research three years ago as a Master's dissertation and initially had a limited number of interviews (ten) that I was able to conduct. However, through word-of-mouth, a sense of genuine excitement was generated and more people expressed their desire to be a part of this conversation. In sharing the main arguments that animate this article, my interviews and the subsequent conversations that took place unfolded as "a collaborative moment of making knowledge" (DeVault \& Gross, 2007, p.181; Paget, 1983). I wanted my methodology to be further cultivated in pointing to the importance of a praxis that moves epistemology and knowledge production "away from an imperialist model of knowledge extraction and instead collaboratively shape it” (Falcón, 2016, p.174). My research is the culmination of these continuing conversations and a generative sharing of lived experiences that moved beyond the limitations of the research format in earlier stages.

Despite its concern with the externalisation of gender and sexual non-normativity onto migrants and noncitizens, my research data itself remains limited in its representation of migrant and stateless Bidoon queer experiences in Kuwait. Kuwait holds a larger population of non-citizens than it does citizens and this has driven violent discourses and policies aimed at restructuring the country's "demographic imbalances" (Aljarida, 2020). This paradigm of nationalism, xenophobia, racism, and capitalism is imbricated within the Kafala (sponsorship) system which renders migrants vulnerable to exploitative working conditions that allow for situations of unpaid wages, forced confinement, withholding of passports, arrests, detention, and deportation (Migrant Forum in Asia, 2012). Kuwait also holds a stateless population, the Bidoon Jinsiyya (without citizenship), who are native to the region but did not receive citizenship during Kuwait's modern state formation in 1961. During the mid-1980s, the state enacted active processes of illegalisation and administrative erasure of the Bidoon's historical presence and prevented their access to employment, health care, and education. While an extensive discussion of the state's violent policies, institutions, and structures that both migrants and Bidoon experience and struggle with in Kuwait is beyond the scope and length of this paper, it is important to take into account how citizenship, as an exclusionary technology of power, informs these dynamics and the spaces I am concerned with. The spaces I name and navigate remain specific to me, my interview participants, and their social circles. Contrary to conceptualising these spaces as transcendent or resistant, this is in itself reflective of the exclusionary class-differentiated, gendered, and racialised processes that constitutes such a space, and how these processes delineate the limits of citizenship in relation to Bidoon and migrants. 
Additionally, this research is informed by the conversations that took place in Beirut, Lebanon during Kohl's Writing Workshop for this issue on Queer Feminisms. Being a part of a queer collective in that space allowed me to think about our shared anxieties around what it means to write as a queer feminist in contexts where doing so can have difficult consequences. I found myself understanding the different ways in which I have been erasing myself and my narrative throughout previous drafts of this work, my desire to hide queerness in academic jargon, and my remaining ambivalence around questions of authorship. Even as I write this now, the desire to erase my own account from the research bears on, but perhaps it is precisely why I must include it. In our sessions, we also meditated on and grappled with our desires for a queer archive, what it can look like, how difficult it is to imagine ourselves connected to such an archive, and the inability to read oneself through local histories of queerness instead of global north academic texts. Although the purpose of this paper is not to "uncover" or narrate a queer archive, I am thinking that perhaps these queer intimacies and encounters that I am concerned with, no matter how ephemeral, can be read as a moving archive.

\section{A Note on Sex/Gender/Sexuality}

In her reading of Bareed Mista3jil, a collection of life narratives of Lebanese queers, Dina Georgis argues that naming Arab sexualities is contested because "there is no easy way to make sense of the historical entanglements of precolonial traditions, colonization and sexual shaming, and gay epistemologies in the lives of present-day Arabs" (Georgis, 2013). Similarly, I do not seek to disentangle the polyvalent complexity of contemporary discourses of sexuality as mapping onto clearly distinguished binaries of "traditional" sexualities that articulate themselves through local and community dialects versus hegemonic "globalised" sexualities of LGBTQ categories. Instead, I am much more interested in analysing the epistemological resonances of some Kuwaiti-specific terminologies and articulations of queerness that cannot be separated from queer practices, and how these resonances are intimately linked to state and society regulations of gender and sexual non-normativity.

As Nour Abu-Assab, Nof Nasser-Eddin, and Aydan Greatrick argue, "people with non-normative sexualities and genders are not always necessarily self-identified LGBTQI individuals" (Abu-Assab et al., 2018, p.186). To sketch some Kuwaiti terminologies that categorise non-normative genders and sexualities is to delve into "an ambiguous nebula of overlapping and shifting assignations and (self)cognitions" (Najmabadi, 2013, p.225). Some of the dialects that are used take on a different signification according to context and to speaker, as they can be used in derogatory ways, but are also taken up as subject-positionalities. Terms like Jins (plural: jnoos), Khaneeth, and Tarf are often used to describe male femininity, whilst Jins Thalith (The Third Sex) and "She-Male" are understood-asoverlapping male femininity, homosexuality, and transness. The term boyah (plural: boyat) is used to refer to forms of female masculinity and butch subjectivities, with homosexuality being considered one of the ways in which boyat further their deviance and moral degeneracy as masculine subjects. Much of the popular discourse around boyat can be found in media; Kuwaiti talk shows discuss the masculinisation of women el-Mustarillaat, as a "foreign" social phenomenon that needs to be eradicated, specifically pointing to its "spread" in high schools. The figure of the boyah becomes enveloped in discourses around psychological and hormonal imbalances, Satanism, and Western "imitation" (Almubayei, 2010). For example, Kuwaiti religious cleric Nabeel Al-Awadhi argues that "the coinage of boyah in itself is 
problematic because it is not ours - it imitates the English word boy and combines it with an Arabic feminine suffix. This is an example of how this sexual phenomenon is a direct imitation of the West," to which Noor Al-Qasimi argues that "what could be said of the boyah identity is that it is not merely an imitation of the west achieved through globalizing forced but a re-appropriation of it - an integration of a western linguistic term with an Arabic suffix that results in a co-constitution not only of sexual subjectivities but also of cultural logics" (Al-Qasimi, 2011, p.259). The externalisations of non-normative genders and sexualities onto the "foreign" and "alien" operate in a double sense. First, it works through the state's ahistorical disavowal of non-normative sexualities and genders in the region, and their various local articulations, to instead produce a reading of any deviation from the naturalised heterosexual gender binary as a Western imposition that can only ever materialise in the foreign language of LGBTQI+ categories. Second, the repeated invocation of queerness in relation to the foreign can be seen in the number of arrests reported in the Kuwaiti media that focus on queer migrants and non-citizens who are subsequently deported (Almazidi, 2020).

Writings on queer subjectivities in Kuwait necessitate a note on how meanings of gender and sexuality are specific to "a nexus formed not simply by transnational diffusion of concepts and practices from a Western heartland to the rest, but is also the product of the sociocultural and political situation" (Najmabadi, 2011, p.535). One needs to do the work of considering the significations of sex and gender in a particular context rather than employing an inapplicable universalised Western sex/gender system. Discourses around gender and sexual non-normativity make it difficult to disentangle homosexuality, transness, and different forms of non-normative sexuality and gender. Indeed, "to better address gender and sexual rights in the MENA region, there is a need to recognise the intersectionality between gender and sexuality, as well as class, religion, and nationality. Experiences in the MENA region are not homogenous" (Abu-Assab et al., 2018, p.186). This epistemological observation is crucial to understanding different logics of sexuality beyond the global north. In particular, I want to emphasise on the importance of considering the linguistic contours of sex and gender and their epistemological resonances when thinking about how the Arabic-Persian word for sex Jins is never just about sex, with its "polysemic usage as an adjectival modifier between male and female, often meaning gender (masculine/feminine), genus (type), and at times sexuality (a modifier of desire)" (El-Shakry, 2017, p.66). The genealogy of Jins carries with it new and old meanings of biological sex, genus, sexual relations, and sexual desire in informing how sex, gender, and sexuality are aligned and configured.

Afsaneh Najmabadi has noted the significance of tracing semantic shifts in the word Jins, which came to mean sex during the 20th century as a result of translation movements from Western Psychology, medical treatises, and developments in Islamic jurisprudence. Such developments include the usage of Jins in its adjectival form for differentiating man from woman (ikhtilaf jinsi) and framing their distinctions as opposite and complementary sexes (Najmabadi, 2013, pp.215-219). Rather than thinking about investments in the heteronormative binary sex/gender system through Adrienne Rich's framework of "compulsory heterosexuality" as an institutional and structural construction of heterosexuality as the ideal norm (Rich, 1980), I want to instead think about the disciplinary work that ikhtilaf jinsi does. As Ahmed Ibrahim reminds us, there is a limitation to deploying conceptual tools "out of the contexts in which they are designed," whereby saying "that heterosexuality... is compulsory is to completely gloss over the ways in which Western epistemes have contributed to the production of a stable 'subject' that may voluntarily reject their heterosexualization" (Ibrahim, 2020). Ikhtilaf jinsi relies on an insistence of its naturalisation and its value 
for the traditional family and the nation writ large, meaning that any deviation from a naturalised heterosexuality continues to be measured against the established binary distinctions between men and women. In this sense, ikhtiflaf jinsi produces gender and sexual norms that condition the (il)legibility of subjects in their normativising power. It becomes clear, then, how non-normative sexualities in Kuwait are often primarily made "legible" and readable through an aesthetical performativity of femininity and masculinity. This informs much of the ways in which Kuwait operates its biopolitical governmentality, and is evident in in both societal discourses, whether in the form of media representations, talk shows, or otherwise, and in the framing of Article 198 of the Penal Code which criminalises "imitation of the opposite sex" (Almazidi, 2020).

The structure of el-ikhtilaf iljinsi hints at how sexual non-normativity can become unthinkable or unreadable when one is publicly presenting in gender normative ways. This is further evident in past conversations in Kuwait's National Assembly, as well as on social media, around the reinstitution of military inscription: they almost always invoke questions around homosexuality, with the narrative being that feminine men need to be "re-masculinised" through military training (Alsry'e, 2017). Some of my participants spoke of how performing as a "masculine gay" instead of a "feminine gay" constitutes vastly different experiences in how they engage with public and private spaces in Kuwait. For example, Jassim says that

Masculine gay men have very different experiences as they're read as straight in the public... They definitely get better treatment, better jobs, better service, even at the hospital. I've had occasions where l've been overlooked because of my appearance. Some masculine gay men present masculine as a conscious decision because it gets you places; successful career, successful dating life; it's helpful for you both in the public eye and within the community; because you know.... you're either a man or a woman.

Similarly, Yousef says that he presents differently according to the context:

If l'm being myself... I'm more feminine than masculine but because l'm used to acting masculine with my family, extended family and in government spaces, it's easy for me to do that. I dress in a dishdasha, act firm and strict with a lower pitch voice, and I actively select to do that.

The spectrum of gender normativity and where one is located along it and outside of it shapes and dictates the amount of targeted harassment and violence transwomen and feminine-presenting men receive from both civilians and police officers alike. Jassim recalls an instance in which their more femmepresenting friends Ahmed and Musa were out at The Avenues mall, where

...they were walking around on the ground floor and someone was looking down at them, laughing, and making comments, and then they spat on them... so I know it can get that bad even in places like The Avenues where there's high security cameras, people watching, but you know, who's gonna stand up for them?

Similarly, Nidhal spoke of how they were verbally harassed at the mall as 
....a group of older women were sitting together. As I walked past them, they bluntly gave us looks of disapproval saying "shal ashkal hathi?" ("what are these abominations?"). It's just not fair, but that's what I see when I go to big public spaces like malls.

While the heteronormative sex/gender system that demands this compliance to the gender binary can affect anyone who is gender non-normative, state-mediated legislative violence targets transwomen as it interpellates transwomen as the main punishable subjects.

\section{Policing the borders of sex/gender}

Under the debauchery and immorality section, Article 193 states that consensual sexual intercourse between two men over the age of 21 shall be punished with imprisonment of up to seven years. The basis of this legislation is traced back to British colonial powers from the nineteenth century to the beginning of the twentieth century. The sanctions introduced by the British to the region mirrored the criminalisation of the "act of sodomy" in Britain where the hanging of homosexuals was then replaced with imprisonment and other forms of fining (Al Farchichi \& Saghiyeh, 2012). Article 193 does not use the terminology "homosexuality" or "gay." Although the much later introduced Arabic term shudhudh jinsi in medicalscientific and literary discourse is meant to "express the contemporary European concept of 'sexual inversion' or 'sexual perversion'" (El-Rouayheb, 2005, p.158), it, nevertheless, is not mentioned in Article 193 and is generally not widely used in Kuwait. Prior to the onset of colonialism, Arab and Muslim discourses of same-sex relations, behaviours, and desires were not regarded as part of a "one overarching phenomenon" and thus did not have the same weight in legal-juridical discourse as it did in the West (p.6). Furthermore, the law itself only addresses "male homosexuality" with no mention of women's same-sex relations. This is not, however, a celebration of women's non-normative sexualities. As I have previously discussed, discourses on women's same-sex relations are mainly manifested through the figure of the boyah who is considered an immoral but not a criminalised subject. Perhaps one way to think about this absence of illegality is through considering that, "...for women who have sex with women, their sexual practice seems to be considered as less 'disturbing' to the patriarchal gender order, because a sexual encounter between women is thought of as not involving a phallus, and thus not involving clear penetration," whereas "Sex between men is seen as the most threatening to the patriarchal structure, because it involves penetrative sex and a phallus is directly involved" (Abu-Assab et al., 2018, p.173).

Whilst information about the legislation itself is available, there is a lack of access to court cases and published sentences are extremely rare, thus posing further methodological difficulties (Al Farchichi \& Saghiyeh, 2012). Although the actual sentences of these cases are not clear, arrests usually happen when there is a public display of sexual intercourse, with the case often being framed in the language of "public indecency" and "immorality." The arrests that are documented after 2007 show that most are charged with Article 198 rather than 193 (Wikiislam, 2013). Through my research, I have found that arrests of queer migrants for sex work tend to be more prevalently reported in Kuwait, further establishing the salience of imagistic discourses around the "dirty" alien and racialised migrant Other against which a pure and "clean" Kuwaiti Self is measured and produced. Persecution of queer migrants provides a convenient pretext for deportation of non-citizens. For example, in 2017, Gulf News reported the 
deportation of "76 gay men as part of a 'morality' crackdown" with suspects being charged under Article 193 and 198 (Gulf News, 2017). Understanding the invocation of queerness in relation to the "foreign" in this specific way requires a recognition of state-class relations whereby the instability and temporariness of residency for migrants and the total lack of citizenship rights allows for an externalisation of gender and sexual non-normativity onto non-citizens as "culpable" subjects who neither represent nor belong to the nation.

In 2007, the National Assembly voted to amend article 198 and include that "imitation of the opposite sex" shall be punished by imprisonment up to one year, a 1000 Kuwaiti dinar fine, or both (Kuwait's Penal Code, 2013). Informed by his engagement with a committee for the Study of Negative Phenomena Alien to Kuwaiti Society, lawmaker Waleed Al-Tabtabaei proposed the amendment to Legislative and Legal Affairs in the midst of allegations of monetary corruption against several cabinet ministers and repetitive dissolution of parliament (Almazidi, 2020). The committee faced considerable public backlash that accused it of attempting to limit constitutionally guaranteed freedoms such as proposing to "impose strict controls on private parties and gatherings, challenging the legal definition of 'privacy' in order to further regulate people's personal lives and conduct, opposing TV shows and concerts that they consider immoral" (Human Rights Watch, 2012). While the committee's proposed law to ban "revealing" swimwear for women was met with intense opposition, the amendment to Article 198 criminalising the "imitation of the opposite sex" received a unanimous vote from $40 \mathrm{MPs}$. The committee's MPs' frustrations with their inability to pass laws that control women's social autonomy found a victory in the passing of the amendment to Article 198. Attempts to constrict women's autonomy belong to a long history of moral panics that reveal how "itizenship and national imaginaries are gendered and the ways that sexual difference operates and is operationalized politically," as Maya Mikdashi (2014) frames it, whereas the amendment to Article 198 received no attention, which is symptomatic of the national investment in heteronormative binary sex/gender system.

The vagueness of the wording in the law and the lack of specification as to what counts as "imitation" gives much leeway for the police member to decide what constitutes one. As some transwomen have reported, even as they were dressed in male garbs, the police arrested them for having "a soft voice" and "smooth skin" (Human Rights Watch, 2012). My interviewee, Mariam, shared how her experience as a transwoman in Kuwait changed after the amendment was passed mentioning that after the law passed:

... it became very difficult for us to go to government hospitals because of the risk that the workers would call the police on us and the treatment changed from being professional medical workers to outright refusing to treat us because we are trans, even though the treatment we are seeking can be anything from a regular check-up, a flu or dental treatment; not necessarily trans-specific treatment.

The ambiguous language of Article 198 in defining what counts as gender "transgression" has led to multiple forms of harassment for anyone who is gender non-normative. However, it is transmisogyny that interpellates transwomen as the main punishable subjects, and it is a patriarchal abjection of femininity that shapes the modes through which transmisogynistic violence is articulated. Transwomen arrested under Article 198 frequently experience physical and sexual abuse aimed at "re-masculinisation" through shaving hair and other violent means. On June 5, 2020, a series of Snapchat videos by Maha Al-Mutairi, 
a Kuwaiti transgender woman, were publicly posted while she drove to a detention centre to be arrested and jailed under Article 198 for "imitating women." Maha's videos detailed how she had been repeatedly arrested and jailed in men's prison cells where she was physically and sexually assaulted by the police. Maha's experience of such systemic transphobia, and more specifically, transmisogyny is facilitated by Article 198. When we spoke about Maha's case, Mariam recalled several instances of police harassment, especially whenever she travels through Kuwait's airport:

Police harassment and exploitation are endless - at checkpoints, at the airport, or when you are detained. And they know where you live; they will constantly show up in the area to try to arrest you again. They ask for your number, call you non-stop, threaten to arrest you if you don't show up at their private apartment for sex or if you don't send nude photos, and subsequently blackmail you with those too.

The amendment to Article 198 gives authority to the police to interrogate what they consider to be gender and sexual "deviation." The threat of arrest under Article 198 allows for both the police and other civilians to not only surveil and restrict the disciplinary borders of sex/gender through criminalising, reporting on, and blackmailing people who present in gender and sexual non-normative ways, but it also specifically sanctions transmisogynistic violence towards transwomen through verbal, physical, and sexual abuse (Almazidi, 2020).

My friend Nidhal, who identifies as gender non-binary, has spoken to me about an encounter with a police officer at a gas station:

As I was walking in, I noticed there was a cop-car outside, and for me whenever I see cops, I always mentally prepare myself for an altercation ... when I went in, the cop was walking around; we intersected at some point and he bumped me with his shoulder very hard ... I looked at him and said, "what's wrong with you?" and he replied, "what's wrong with you? Why are you walking like that? Why are you dressed like that? Why does your hair look like that? What have you done to yourself?" Because I know it's illegal to "cross-dress" in Kuwait, I realised that, obviously, he perceives me to be a man with feminine traits or with a feminine haircut or shorts that are too short ... so I told him, "you're basically accusing me of imitating the opposite gender and that's illegal in Kuwait... you're making that observation without any proof." They need actual proof like me wearing makeup or carrying a purse or something that can be used as physical evidence if they take me away. I added, "I can sue you and get you in trouble." Obviously I said that comfortably because I know my family name will help in this case.

Family names play an important role in any social interaction in Kuwait. Kuwaiti surnames are recognised in their signification of ancestry, economic power, and social standing (O'Shea \& Spilling, 2010, p.90). Every one of my citizen-participants agreed on the value of their family names in privileging them out of encounters with the police. There is also a commonality in having family members who are part of the police force and the Ministry of Interior, where the family name would act as some form of limitation to the police officer's actions. It is clear to notice how non-citizens can be excluded from this narrative. If Nidhal had been a migrant or a Bidoon, this encounter would have carried on very differently. 
As I have previously mentioned, queer bodies in Kuwait are read as non-normative mostly through a subject's exerted feminine or masculine presentation and energy whereas when, to put it in the words of one participant "it doesn't show," the subject is read as heterosexual. This is further exemplified in 25year-old Ahmed's account of his interactions with the police during checkpoints, as he describes how police officers exercise their authority flirting with "feminine looking" men:

They especially flirt with femmes whom you can't really arrest cause they're not feminine enough to be accused of cross-dressing. If it was really a "she-male" in the car, the cop would feel like he has more authority to take it a step further and sexually harass or arrest them.

This account returns us to the importance of recognising the intersectionality between and inextricability of gender and sexuality in this context (Abu-Assab et al., 2018, p.174). Transmen, boyat, and masculine women have different experiences with the police, and are much less likely to be arrested under Article 198. If one's ID reads "female," it can potentially be more of a risk for the police officer to arrest a "woman," and this partially stems from Kuwaiti societal norms around complexes of honour and shame that are located in the category "woman." This is more reflective of the centrality of the complex of honour and shame to Kuwaiti sex/gender system, and the infantilization of female masculinity, rather than a celebration or privileging of women's sexual and gender non-normativity. Hamad, who identifies as a transman, has spoken about his interactions with the police during a time when he had shaved his head and worn a binder:

A police officer stopped me, read my ID, and asked, "are you a girl or a boy?" I replied, "what do you think?" I don't know if he was okay with it or if it wasn't worth it for him but I think that maybe when I spoke, he could tell that I was a female so he didn't want to insinuate something else, and he just let me go.

This sort of "passing" is not necessarily applicable for public spaces or in interactions with other civilians. My friend Ayesha, for example, has spoken about the public harassment her girlfriend faced when she shaved her head: "a man began screaming at her, yelling 'you'll never be a man' when we were in the parking lot at Sultan Centre."

Police checkpoints typify a sort of unfolding of the gendered and sexual discourses I outlined earlier. Much of this analysis is informed by my participants' accounts and their repeated mention of checkpoints as an important site where anxieties are felt, whether through tensions or instances of flirtations from police officers. The Ministry of Interior designates multiple police checkpoints to operate throughout Kuwait, with the aim generally being to check driving licences, ensure safety, reduce crime rates, monitor undocumented migrants, and act as a form of surveillance (Kuwait Times, 2015). The checkpoint can be read not only as a material site onto which one is required to present identity documents, but also as a space that highlights an unravelling of power relations within which subjectivities are constituted.

\section{On Spatial Recognition, Agency, and Affect}


Understandings of queerness as inherently transgressive limits meanings of recognition and visibility, as it operates with a teleological narrative of "coming out" that privileges a particular form of agentival resistance. What is understood as an inability to be "visible" and "recognised" on homonormative, orientalist, and homonationalist terms erases the agency of queers in this context.

Humanist and feminist autonomy literature that operates with notions of a revolutionary subjectivity and carries with it "philosophical assumptions about the "true self" (Hutchings, 2013, p.14) has located agency in "the political and moral autonomy of the subject" (Mahmood, 2005, p.7). When the marker for agency becomes the subject's capacity to "resist... dominating and subjectivating modes of power," it reiterates a form of progressivist politics that reads Kuwaiti queer bodies, whose being does not "map onto the logic of repression and resistance" as passive or docile (Mahmood, 2005, pp.7-14). Giving a sense of the ways in which queer subjects inhabit and engage the world requires an understanding of agency as emerging "through an analysis of the particular concepts that enable specific modes of being, responsibility, and effectivity" (Ibid.). I am, then, not interested in locating examples of "resistance" or "subversion" as an indication of an agentival capacity. What I am seeking after is a complex and plural process of an "agentival activity" (Madhok, 2013) that can only be understood through an examination of the discursive and practical conditions that enable its enactment - conditions that I hope to have somewhat mapped out throughout this research. It is important to consider how subjects articulate their subjectivities not at a distance from norms, but rather through "the gaps opened up in regulatory norms" (Butler, 1993, p.22).

I explore the centrality of spaces to this agentival activity as one way of expanding a critique of "power's investment, not just in the regulation of bodies and subjectivities, but in their movement" (Ritchie, 2010, p.149). In this perspective, I am trying to formulate an understanding of spatial embodiments that captures how queer subjects carve out a different mode of being, one that articulates a distinctive form of what I term "spatial recognition." I use spatial recognition to describe recognition in a sense that is felt through spaces that are both material and imagined, public and private, in both fleeting and long-term ways. These are spaces that are present without legal or political recognition. My participants and I spoke together about specific hookah (sheesha) cafes, trendy local coffeeshops, chalet (beach house) gatherings and parties, car parks, private homes, art galleries, gyms, diwaniyas, basements, and boutiques. These are spaces through which a form of spoken and unspoken acknowledgement takes place, unfolding in the shape of conviviality, exchanged looks, nods, smiles, and stares. Spatial recognition operates with the centrality of feeling for others, the establishment of connections with others, affecting, and being affected, and contains within it possibilities of different modes of living with oneself and with others that do not follow the developmental terrain of a "coming out" process, yet offer a lived form of recognition.

The knowledge of such spaces, either public "hotspots" or private gatherings, would not be possible without some form of social networking either through word of mouth, mutual friends, or online applications. The spaces queer people create and inhabit are not homogenous, fixed, or coherent spaces, "existing in opposition to and as transgressions of heterosexual space" (Oswin, 2008, p.89). Rather, they are "elusive, ephemeral, and always in the process of both becoming and disintegrating" (Knopp, 2007, p.50). For example, my interview participant Fatima has spoken about how some of these spaces operate as "a ticking time bomb," anticipating that 
...one day the public is going to discover this place and it's gonna stop becoming as welcoming as it is. So it's usually temporary. Being discovered, or the possibility of straight people infesting the place and it's gonna stop being what it is or the cops are going to find out and the owner would get into trouble and they'd sort of have to kick us out.

I situate my analysis of these spaces within a critique of Kuwait's state-class structure that informs sociopolitical dynamics between citizens, migrants, and Bidoon in ways that cannot be detached from any account of queer life and intimacy. It is important to emphasise that I am not describing "queer spaces" that are often framed as resistant, progressive, or dissident spaces. To conceptualise it in that way is to privilege sexuality above all other co-constitutive processes of subject formation, thus failing to examine how queer subjects are "simultaneously raced, classed and gendered bodies" (Oswin, 2008, p.91). Rather than thinking in terms of "queer spaces" as oppositional to a non-queer space, what I am giving an account of are spaces of inhabitation where non-normative sexual and gendered subjects experience and feel moments of recognition, intimacy, and conviviality.

As I have noted in my methodology section, my navigation of these spaces in Kuwait is mostly limited to citizens, and this is reflected in the spaces I am describing and conceptualising. However, a refusal to detach queer socio-spatial relations from the structures of citizenship, the violence of the Kafala system, and the systemic dispossession, exclusion, and stigmatization of Bidoons that shape and inform everyday life in Kuwait is foundational to my understanding of spatial recognition.

The limitations to accessing the same modes of socio-economic living and attached to Kuwaiti citizenship, as shaped by Kafala and social relations of production, hints at how migrant and stateless queers in Kuwait can be excluded from many of the spaces I am concerned with. It also shows how citizenship operates as a racial-class and gendered apparatus that intersects in its production of what Sofian Merabet aptly frames "hierarchies of urban mobility" (Merabet, 2014, p.74). Pointing to the ways in which queer spaces are classed shows how the difference does not only lie in "material wealth and economic security, but also... affects our access to things, relationships, experiences and practices which we have reason to value" (Binnie, 2011, p.22). This is exemplified in Jassim's account of his interaction with a Lebanese gay man working in a salon, as he describes how although they are friendly with one another,

...I know that I'm not gonna see him outside of the salon, like, I'm only gonna see him in this context while he's servicing me, you know? We don't really mingle that much with one another.

Similarly, Fahad spoke of a hierarchy in queer spaces:

People in certain circles only invite people with certain family names, it depends on if you're rich or not, if you're on the same socio-economic level, if you dress yourself in brands or not, if you're "educated" ... They become extremely judgemental.

Some participants also shared that it is not that uncommon to see "no Bidoon!" and "no South Asians!" on gay dating apps in Kuwait. On the relationship between queer cyberspace and Beirut, Mathew Gagné analyses the popular gay male dating website GayRomeo.com's virtual structures and argues that "local identity politics are textually and discursively linked via profile categories and self-description through the 
lexicons of gender, ethnicity, nationality, and sexuality" (Gagné, 2012, p.128). Similarly in Kuwait, intimate and sexual encounters are mired in these exclusionary practices that are shaped by socio-economic and political realities.

Gender, race, citizenship, and class can limit and prevent a queer subject's accessibility to and movement across the spaces I mentioned. Lesbian and non-binary women described how they are less likely to be "hanging out" at chalet parties and sheesha spots with other friends, indicating that mobility and movement across spaces can be inhibited according to the subject's location in relation to Kuwait's sex/gender/sexuality systems, patriarchal gender structures, and societal norms that can restrict women's mobility more so than men's and also, in a way, inform women's interactions with the police. This is a location that is further shaped by family relations and age. This does not, however, dismiss the existence of homoeroticism through homosociality and social relations that produce spaces of recognition for queer subjects. In my own experience, I have found homosociality to have eased my queer experiences and in fact, I find it less difficult to date a woman in Kuwait. What I am suggesting, then, is that although the spaces themselves are specific to the queer subject's location, the framework of a spatial recognition does not emerge out of a sexual rights framework attached to dominant modes of visibility and to "coming out" narratives. Rather, fostered through social relations, it can provide an insight into a spatial ontology that indicates how queerness can be inhabited and lived in different ways. It is my hope that spatial recognition would allow us to think about what can creatively follow from such an account, as a generative and ongoing conversation rather than a foreclosing argument. 
Kohl 6.3

\section{References}

Abu-Assab, N. \& Nasser-Eddin, N. \& Greatrick, A. (2018). Reconceptualising and contextualising sexual rights in the MENA region: beyond LGBTQI categories. Gender \& Development, Vol. 26, 1, pp. 173-189.

Ahmed, S. (2004). The Cultural Politics of Emotion. London: Routledge.

Al Farchichi, W. \& Saghiyeh, N. (2012). Homosexual Relations in the Penal Codes: General Study Regarding the Laws in the Arab Countries with a Report on Lebanon and Tunisia. Helem. http://daleel-madani.org/node/5802

Aljarida. (2020). Fixing Demographic Imbalance. Aljarida. (Online) Available at: https://www.aljarida.com/articles/1595265244925065100/

Almazidi, N. (2020). Policing the borders of sex/gender in Kuwait: on transmisogyny and state-mediated violence. LSE Engenderings. (Online) Available at: https://blogs.Ise.ac.uk/gender/2020/07/29/policing-the-borders-of-sex-gender-in-kuwait-ontransmisogyny-and-state-mediated-violence/

Almubayei, D. (2010). Articulations of Identity within Kuwaiti High School Cliques: Language Choices in Boyat and Emo Filipino Youth Groups. PhD, The University of Texas at Arlington.

Al-Qasimi, N. (2020). Queerer Than Queer: Anti-Ancestry, Disavowal, and the Emirati Post-Oil Generation. GLQ, 26 (1): 63-101. doi: https://doi.org/10.1215/10642684-7929111

Al-Qasimi, N. (2011). Ladies and Gentlemen, Boyahs and Girls: Uploading Transnational Queer Subjectivities in the United Arab Emirates. In Radha S. Hegde: Circuits of Visibility: Gender and Transnational Media Cultures. NYU Press.

Al-Samman, H. \& El-Ariss, T. (2013). Queer Affects: Introduction. International Journal of Middle East Studies, Vol. 45, 2, pp. 205-209.

Alsry'e, H. (2017). Mandatory Conscription. Alanba. (Online) Available at: https://www.alanba.com.kw/kottab/hamad-alsarea/745445/15-05-2017\%D8\%A7\%D9\%84\%D8\%AA\%D8\%AC\%D9\%86\%D9\%8A\%D8\%AF\%D8\%A7\%D9\%84\%D8\%A5\%D9\%84\%D8\%B2\%D8\%A7\%D9\%85\%D9\%8A/

Bell, D. \& Binnie, J. (2006). Geographies of Sexual Citizenship. Political Geography, Vol. 25, 8, pp. 869873.

Binnie, J. (2011). Class, sexuality and space: A comment. Sexualities, Vol. 14, 1, pp. 21-26.

Bracke, S. (2012). From 'saving women' to 'saving gays': Rescue narratives and their dis/ continuities. European Journal of Women's Studies, 19, pp. 237-252.

Butler, J. (1993). Critically queer. GLQ: A journal of Lesbian and Gay Studies, Vol. 1, 1, pp. 17-32.

Butler, J. (2009). Frames of War: When Is Life Grievable? London: Verso.

Code, L. (1993). Taking Subjectivity into Account. In: Alcoff, L. \& Potter, E.: Feminist Epistemologies. New York, Routledge.

DeVault, M. L., \& Gross, G. (2007). Feminist Interviewing: Experience, Talk, and Knowledge. In HesseBiber S.N.: Handbook of Feminist Research: Theory and Praxis. Sage, London, pp. 173-198.

Dhawan, N. (2013). The Empire Prays Back: Religion, Secularity, and Queer Critique. boundary 2, Vol. 40, 1, pp. 191-222.

Duggan, L. (2002). The new homonormativity: The sexual politics of neoliberalism. In Russ Castronovo and Dana D. Nelson: Materializing democracy: Toward a revitalized cultural politics. Duke University Press, pp. 175-94. 
Duggan, L. (2003). The twilight of equality? Neoliberalism, Cultural Politics, and the Attack on Democracy. Boston, MA: Beacon.

El-Rouayheb, K. (2009). Before homosexuality in the Arab-Islamic world, 1500-1800. University of Chicago Press.

El-Shakry, O. (2017). The Arabic Freud: Psychoanalysis and Islam in Modern Egypt. Princeton University Press.

Falcón, S. M. (2016). Transnational Feminism as a Paradigm for Decolonizing the Practice of Research: Identifying Feminist Principles and Methodology Criteria for US-Based Scholars. Frontiers: $A$ Journal of Women Studies, Vol. 37, 1, pp. 174-194.

Gagné, M. (2012). Queer Beirut Online: The Participation of Men in GayRomeo.com. Journal of Middle East Women's Studies, Vol. 8, 3, pp. 113-137.

Georgis, D. (2013). Thinking Past Pride: Queer Arab Shame in Bareed Mista3jil. International Journal of Middle East Studies, Vol. 45, 2, pp. 233-251.

Gulf News. (2017). Kuwait deports 76 gay men in crackdown. Gulf News. (Online) Available at: http://gulfnews.com/news/gulf/kuwait/kuwait-deports-76-gay-men-in-crackdown-1.2070054

Haraway, D. (1990). Situated Knowledge: The Science Question in Feminism and the Privilege of Partial Perspective. Feminist Studies, Vol. 14, 3, pp. 575-599.

Harding, S. (1993). Rethinking Standpoint Epistemology: What is 'Strong Objectivity'?. In: Alcoff, L. \& Potter, E.: Feminist Epistemologies. New York, Routledge.

Hemmings, C. (2012). Affective solidarity: Feminist reflexivity and political transformation. Feminist Theory, Vol. 13, 2, pp. 147-161.

Human Rights Watch. (2012). "They Hunt Us Down for Fun": Discrimination and Police Violence Against Transgender Women in Kuwait. (Online) Available at: https://www.hrw.org/report/2012/01/15/they-hunt-us-down-fun/discrimination-and-policeviolence-against-transgender-women

Hutchings, K. (2013). Choosers or losers? Feminist ethical and political agency in a plural and unequal world. Gender, Agency, and Coercion. UK, Palgrave Macmillan.

Ibrahim, A. (2020). In and/or/plus Out: Queering the Closet. Kohl: Journal for Body and Gender Research, Vol. 6, 2.

Knopp, L. (2007). On the Relationship Between Queer and Feminist Geographies. The Professional Geographer, Vol. 59, 1, pp. 47-55.

Kollman, K., \& Waites, M. (2009). The global politics of lesbian, gay, bisexual and transgender human rights: an introduction. Contemporary Politics, Vol. 15, 1, pp. 1-17.

Kuwait Times. (2015). 700 checkpoints set up in Kuwait. Kuwait Times. (Online) Available at: http://news.kuwaittimes.net/700-checkpoints-set-up-in-kuwait/

Kuwait's Penal Code. (2013). (Online) Available at: https://www.indexsignal.com/community/threads/206524/

Madhok, S. (2013). Action, agency, coercion: reformatting agency for oppressive contexts. Gender, Agency, and Coercion. UK, Palgrave Macmillan.

Mahmood, S. (2005). Politics of Piety: the Islamic Revival and the feminist subject. Princeton, Princeton University Press.

Mahmood, S. (2008). Feminism, democracy, and empire: Islam and the war of terror. In Joan Scott: Women Studies on the Edge. Durham, Duke University Press, pp. 81-114.

Merabet, S. (2014). Queer Beirut. University of Texas Press. 
Migrant Forum in Asia. (2012). Policy Brief No. 2: Reform of the Kafala (Sponsorship) System. International Labour Organization. (Online) Available at: https://www.ilo.org/dyn/migpractice/docs/132/PB2.pdf

Mikdashi, M. (2014). Moral Panics, Sex Panics and the Production of A Lebanese Nation. Jadaliyya. (Online) Available at: https://www.jadaliyya.com/Details/30261

Nagar, R. (2002). Footloose Researchers, 'Traveling' Theories, and the Politics of Transnational Feminist Praxis. Gender, Place \& Culture, Vol. 9, 2, pp. 179-186.

Najmabadi, A. (2011). Verdicts of Science, Rulings of Faith: Transgender/Sexuality in Contemporary Iran. Social Research, Vol. 78, 2, pp. 1-24.

Najmabadi, A. (2013). Genus of Sex or the Sexing of Jins. International Journal of Middle East Studies, Vol. 45, 2, pp. 211-231.

O'Shea, M., \& Spilling, M. (2010). Kuwait (Vol. 17). Marshall Cavendish.

Oswin, N. (2008). Critical geographies and the uses of sexuality: Deconstructing queer space. Progress in Human Geography, Vol. 32, 1, pp. 89-103.

Puar, J. (2006). Mapping US Homonormativities. Gender, Place \& Culture, Vol. 13, 1, pp. 67-88.

Puar, J. (2007). Terrorist Assemblages: Homonationalism In Queer Times. Durham, Duke University Press.

Puar, J. (2013). Rethinking Homonationalism, International Journal of Middle East Studies, Vol. 45, 2, pp. 336-339.

Rich, A. (1980). Compulsory heterosexuality and lesbian existence. Signs: Journal of women in culture and society, Vol. 5, 4, pp. 631-660.

Ritchie, J. (2010). How do you say "come out of the closet" in Arabic? Queer activism and the politics of visibility in Israel-Palestine. GLQ: A Journal of Lesbian and Gay Studies, Vol. 16, 4, pp. 557-575.

Ritchie, J. (2010). Queer Checkpoints: Sexuality, Survival, and the Paradoxes of Sovereignty in IsraelPalestine. PHD thesis. University of Illinois at Urbana-Champaign.

Sinnott, M. (2013). Dormitories and Other Queer Spaces: An Anthropology of Space, Gender, and the Visibility of Female Homoeroticism in Thailand. Feminist Studies, Vol. 39, 2, pp. 333-356.

Spivak, G. C. (1993). Can the subaltern speak. In P. Williams \& L. Christman: Colonial discourse and post-colonial theory: A reader. London. Harvester Wheatsheaf, pp. 66-111.

Sulttan. (2016). Gay rights in Kuwait: Land of the straight. YouTube. (Online) Available at: https://www.youtube.com/watch?v=NWfZa8NzukQ

Traub, V. (2008). The past is a foreign country? The times and spaces of Islamicate sexuality studies. Islamicate sexualities: Translations across temporal geographies of desire. Cambridge, Mass., Harvard Center for Middle East Studies.

Wikilslam. (2013). Persecution of Homosexuals (Kuwait). Wikilslam. (Online) Available at: https://wikiislam.net/wiki/Persecution_of_Homosexuals_(Kuwait) 